\title{
Sct. Hjælper i Kliplev kirke
}

Af $J . K$. Hansen

I 1400-tallet fandtes en meget kendt og undergørende helgenfigur i nordkapellet i Kliplev kirke. Det var en korsfæstet skikkelse, Sct. Hjælper, hvortil der blev valfartet langvejs fra. Romerkirken har aldrig rigtig godtaget denne sælsomme helgen, og danske forskere har været tilbøjelige til at underkende hjælperkulturens betydning og omfang. ${ }^{1}$

Skikkelsen var i sin tid så kendt og agtet, at da dronning Margrethe i 1411 bestemte om de valfarter, der skulle udføres efter hendes død, blev der givet udtrykkelige adressehenvisninger undtaget for wthet hælghe kors sanctæ hjælp«. Her behøvedes det ikke, samtiden var ikke i tvivl om, at det var korset i Kliplev. Folkelig overlevering vil i øvrigt vide, at dronning Margrethe blev smittet med pesten under bøn ved krucifikset den 14. september 1412. Sygdommen kom til udbrud under hendes ophold i Flensborg, og hun flygtede ud til Okseøerne, hvis hvidtjørnebevoksning formodedes at have en gunstig effekt på sygdommen. Som bekendt døde dronningen derude i oktober samme år.

Også kong Hans skal have bøjet knæ ved korset i Kliplev. ${ }^{2}$ Flere generationer af Ahlefeldterne på Søgård, der havde patronatsretten til kirken, har bedt til og værnet om denne helgen. Når de fik nedlagt nabokirken Bjerndrup og det nærliggende valfartskapel i Årup, samt forsøgte at få nedlagt nabokirkerne i Kværs og Ensted, kan det vel være en aktion til støtte for Sct. Hjælper. På sin gravsten i Kliplev kirke anråber den i 1559 døde Gregers v. Ahlefeldt Hjælperen om bistand på sin sidste færd. ${ }^{3}$ Helgenen skaffede så rige midler til kirken, at var reformationen ikke kommet, havde kirken i dag stået med domkirkeproportioner. $\mathrm{Nu}$ stoppede ombygningen med koret.

I den nyeste tid er der offentliggjort en studie, hvoraf det fremgår, at Sct. Hjælper har været kendt over hele Danmark i middelalderen. ${ }^{4}$ Kulten er kommet hertil sydfra, og Hjælperen var kendt og tilbedt under forskellige navne over hele Europa. Her skal kun gengives de mest kendte navne:

Sct. Hjælper-Sunte Hulper-St. Hülfer-S.Helpericus-Helferin = den, der hjælper i nødens stund.

Kümmerniss-Kummerniss = den, der fjerner alle sorger og bekymringer (Kummer). 
Ontkommer $=$ den, der letter alle betrængte hjerter (undkommer sorgen).

Wilgefortis. Navneoprindelsen uklar. Muligvis afledt af Virgunda, et afsnit af Erzgebirge. Også under dette navn hjælper helgenen, som ovenfor.

Det billedmateriale, som reformationen har levnet ude i Europa, er så broget, at det er svært at få en forestilling om, hvorledes Sct. Hjælper i Kliplev egentlig så ud.

Krønikeforfatteren Anton Heimreich beretter i 1683: »Ligeledes har Sct. Hullfer i Lundtoft Herred på begge korsdage (3.5 og 14.9) været genstand for store valfarter. Helgenens billede stod $\mathrm{i}$ et kapel på nordsiden (af kirken). Billedet hang på et kors og var forsynet med en guldkrone, samt guldsko og -handsker. Det kunne ses gennem et gittervindue, hvor der var anbragt en kollektblok til indsamling af offergaver . $^{5}$ Heimreich må dog have sin viden på anden hånd, for allerede $\mathrm{i}$ 1628 kunne den flensborgske rådmand Jonas Højer fortælle, at der af Sct. Hjælper kun var en træklods tilbage uden arme og ben. Så sent som i 1808 lå resterne endnu på kirkeloftet; men nu er de sporløst forsvundet.
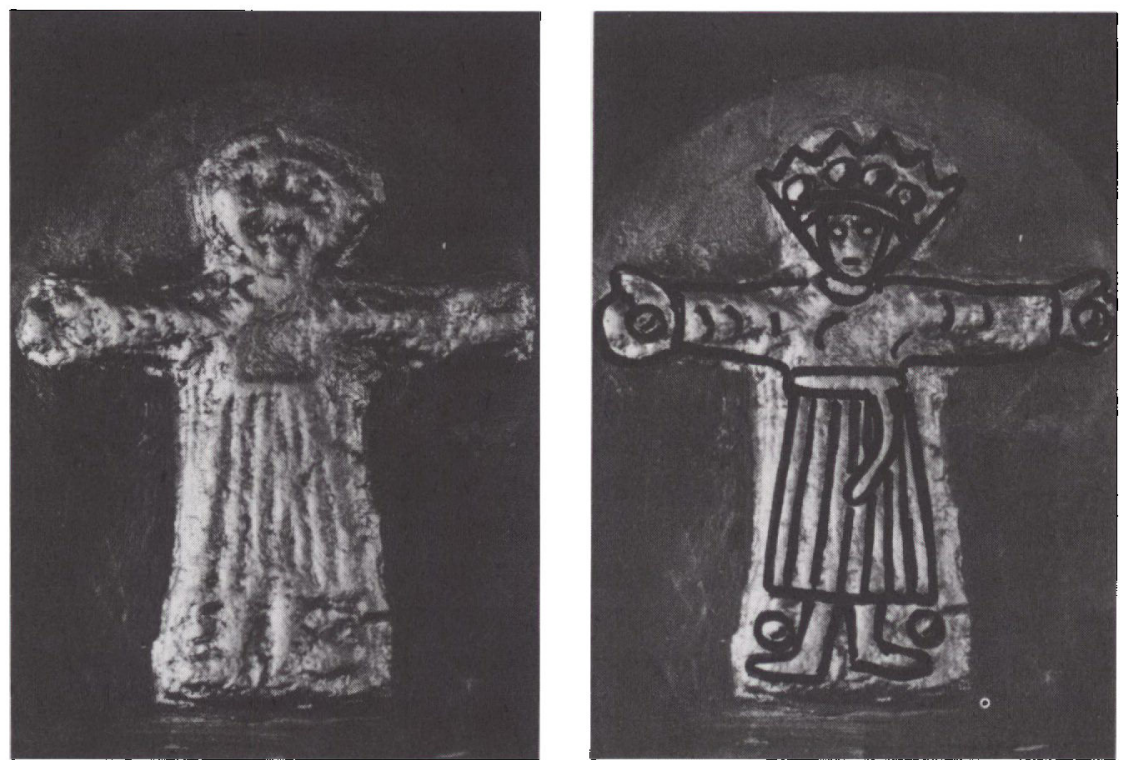

Fig. 1-2. Afstebning af pilgrimsmarke med Sct. Hjalper $i$ Kvars kirke. Originalen md henregnes til 1300-tallet. Pd billedet til hojre er det forsøgt at optegne figurens trak. (Foto: J.K.Hansen) 
Fig. 3. Kalkmaleri af Kümmerniss fra Nikolajkirken i Rostock. Ligheden med Kvars-hjalperen (fig. 1-2) er slående.

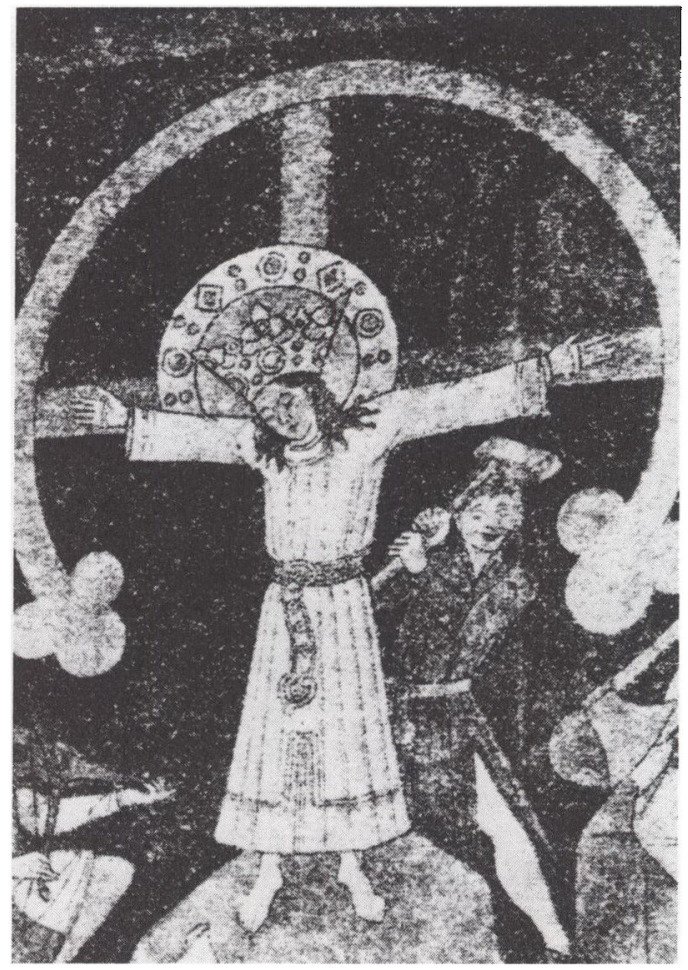

I Kværs kirkes klokketårn hænger en klokke med indskriptionsbåndet: "I året 1472 efter Kristi byrd støbte Bertolt Meier ved Guds hjælp denne urklokke (seier) til Kliplev«. I skriftbåndet er indføjet en afstøbning af et pilgrimstegn forestillende Sct. Hjælper. Et pilgrimsmærke er et lille blymærke, som den andagtssøgende kunne købe til at sy i hue eller kappe. Der er grund til at tro, at dette tegn giver et korrekt billede af Hjælperen i Kliplev, idet broncestøberen må have kendt denne skikkelse.

Desværre er den kun $6 \mathrm{~cm}$ høje afstøbning ret grov, hvortil kommer, at den er medtaget af 500 års skiftende klima. Afstøbningen ses som fig. 1. De ret uklare træk er søgt fremhævet i fig. 2. Det lille ansigt og den spinkle skikkelse kunne tyde på, at helgenen har været fremstillet som en jomfru svarende til afbildningen i Nikolajkirken i Rostock (fig. 3). Der findes yderligere argumenter for denne fremstilling, men herom senere. 

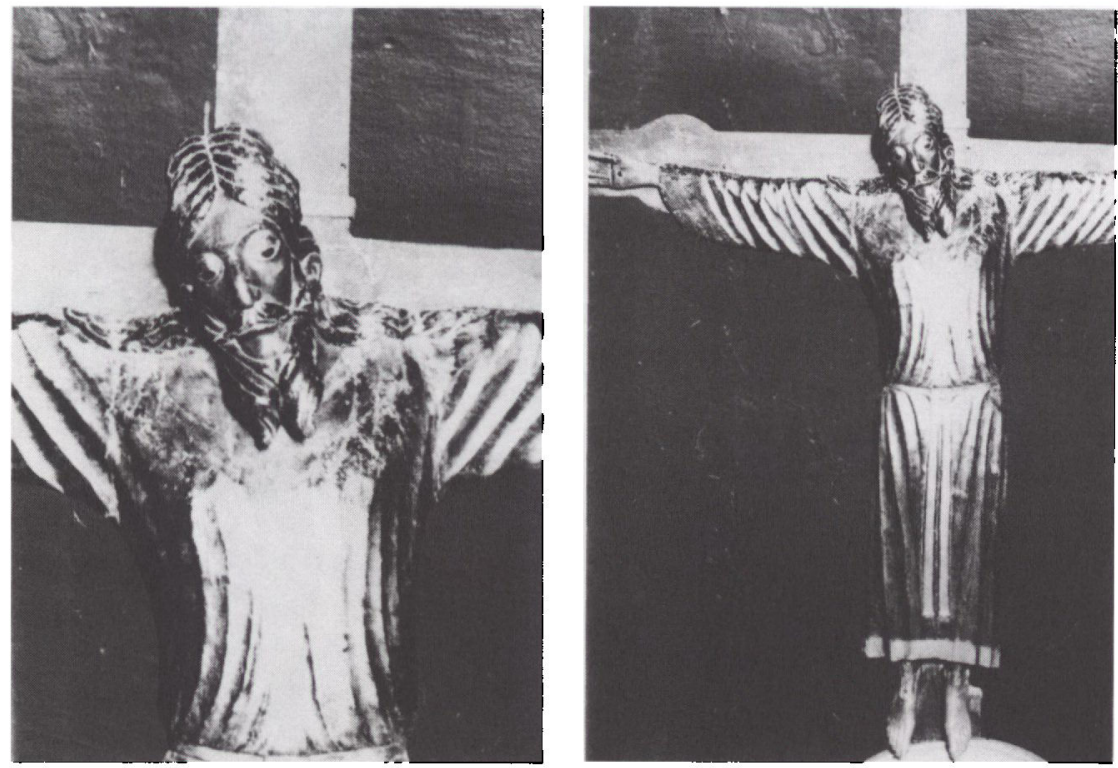

Fig. 4-5. "Volto Santo" - "Det hellige Asyn" fra Lucca med de udpraget palastinensiske trak. Af helfiguren fremgàr, at overfladen pd̉ højre fod er gennemslidt af de mange tilbedere, der har kysset foden, for denne blev forsynet med solvsko.

I den førnævnte Nikolajkirke står der under billedet: "Således står det hellige kors i Wallande (Vælskland-Italien), og der er stor tilstrømning af folk. Store undere sker for dem, der tilbeder det«. På grund af bipersonernes påklædning kan billedet ret sikkert dateres til 1430-50.6

Andre billeder angiver direkte det hellige kors i Lucca (Italien) som kilde, så her må udspringet til legenden søges. Det er det kors, som abbed Nikolaus ca. 1150 omtaler: "Fra Luna til Lucca er der en dagsrejse; her er en bispestol ved Marie-kirken (skal være Martinskirken); der er et krucifix, som Nikodemus lod gøre efter GUD selv, det har talt to gange, den ene gang gav det sin sko til en fattig mand, den anden gang vidnede det for en bagvasket mand «. ${ }^{7}$ I domkirken i Lucca står fortsat det hellige kors, der siden middelalderen har været kendt som "Volto Santo« - Det hellige Åsyn (fig. 4 og 5).

Som det fremgår af billederne, er der tale om en kjortelklædt korsfæstet kristusfigur. Hvor gammelt det er, strides de lærde om, men ifølge legenden (Passionale, Basel 1492) er korset kommet over havet til Luni strand uden for Lucca. Efter præsteligt råd blev korset anbragt på en oksekærre, og det blev overladt til okserne, hvor transporten skulle gå 


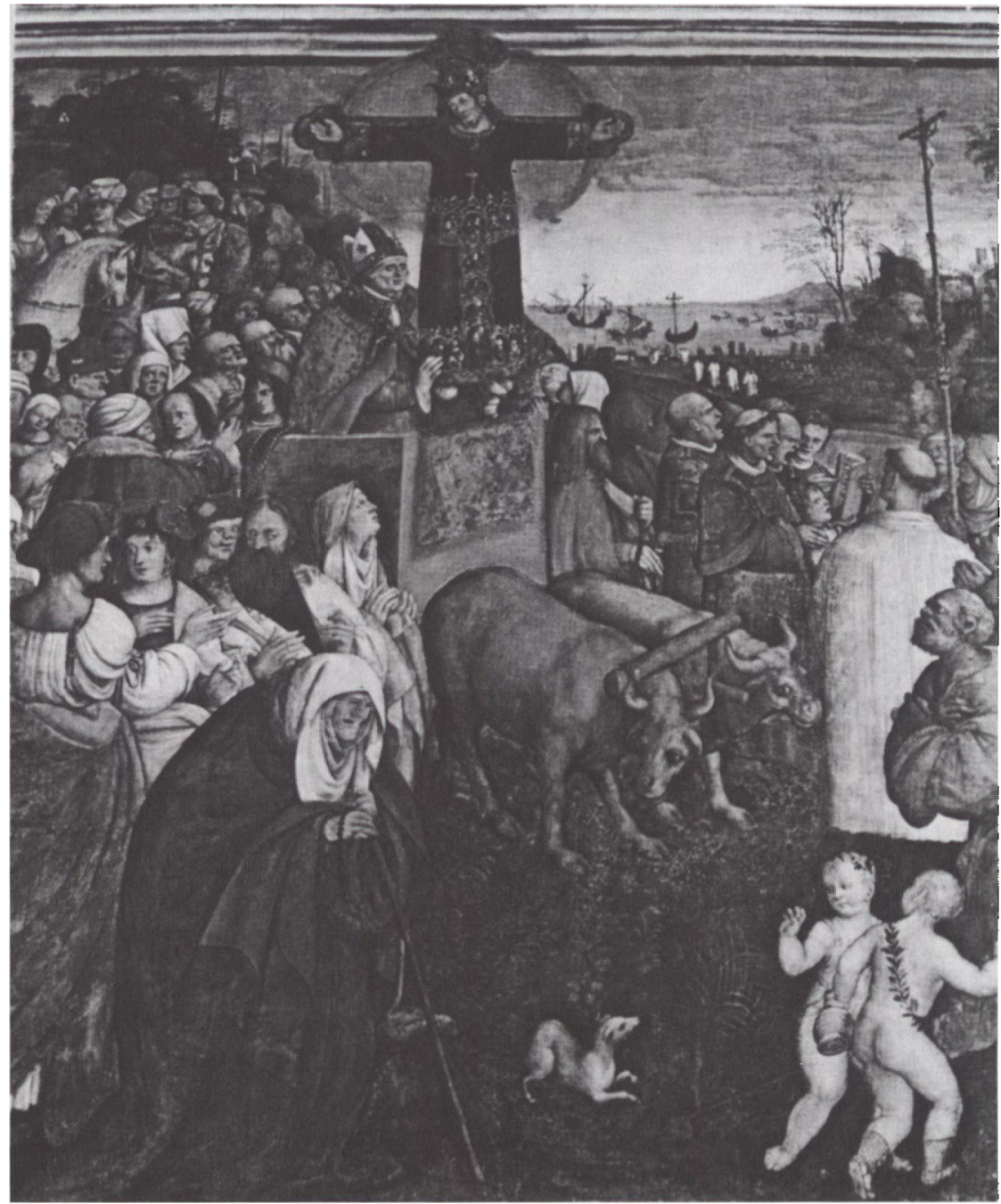

Fig. 6. Korsets ankomst til Lucca. Frescomaleri i S.Frediano kirken. Malet af Aspertino (1508-09).

hen. Således kom korset til Lucca. Et maleri fra 1508 (fig. 6) skildrer begivenheden. Passionalen vil vide, at korset er af jødisk oprindelse og skal stamme fra Corduba (på Sicilien?). Ankomst til Lucca angives til år $782 .^{6}$

Et flertal blandt forskerne er dog enige om, at korset må dateres til midten af det 11. århundrede. Med denne datering savnes der dog en 


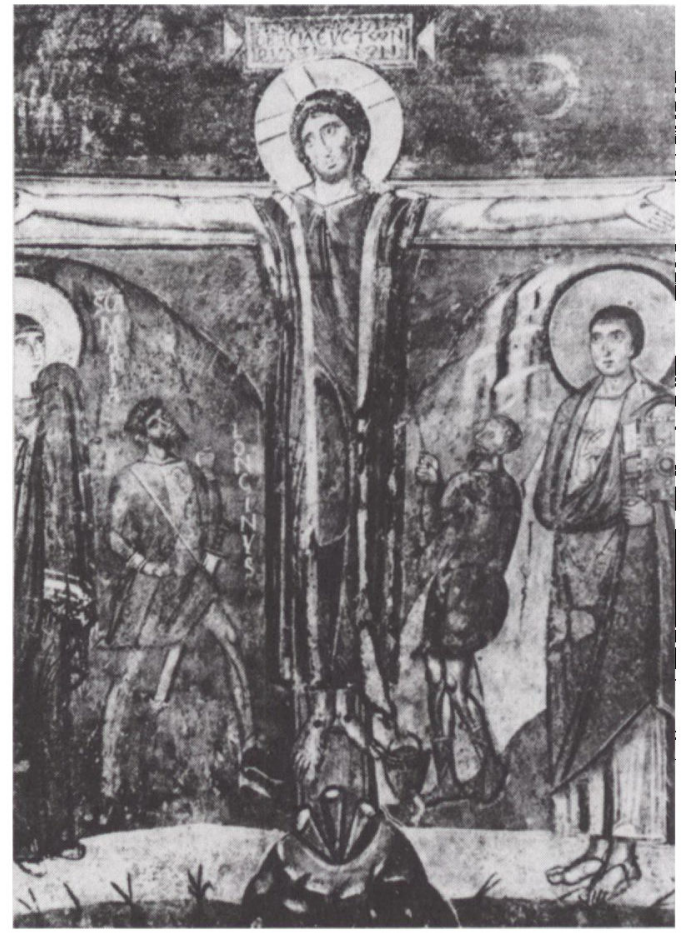

Fig. 7. Fresko fra Santa Maria Antiqua kirken i Rom, der viser traditionen for at afbilde den korsfastede Kristus ifort lang kjortel. Fra ca. år 750.

forklaring på, at korsets ry kunne være så grundfæstet, at kong Wilhelm II i England (1056-1100) kunne aflægge ed ved korset i Lucca. G. Schnürer mener da også, at legendens årstal kan være korrekt. Afklaring fås først med tidsbestemmelse af Majestas-krucifiksene. ${ }^{8}$

Fremstillingen af Kristus på korset iklædt kjortel svarer til tidens afbildninger, jf. fig. 7, der viser en freske fra Santa Maria Antiqva ca. 750. Også oplysningen om, at korset stammer fra Corduba (omend i Spanien) kan meget vel være rigtig, idet vi kender en del gamle kjortelklædte krucifikser fra Catalonien (Majestas). Et eksempel er vist som fig. 8. Ved ankomsten til Lucca blev krucifikset anbragt i San Fredianokirken, der var opført i 685 (Basilica Longobardorum). ${ }^{8}$ Kristusfiguren er $2,5 \mathrm{~m}$ høj og er iklædt en kjortel med vide ærmer. Kjortelen var oprindelig malet rød, men fremtræder nu nærmest sort-brun. Om livet er den sammenholdt af en gylden snor. Det overordentlig udtryksfulde ansigt er udpræget palæstinensisk. Legenden vil vide, at det er skåret af Nikodemus, og Jesus har stået model. Hænderne er naglet til korset med ikke særligt fremtrædende nagler, hvilket $\mathrm{i}$ forbindelse med de 
Fig. 8. En af de gamle Majestasfigurer fra Catalonien. Trods den primitive udforelse ses slagtskabet til Volto Santo (fig. 4-5) tydeligt.

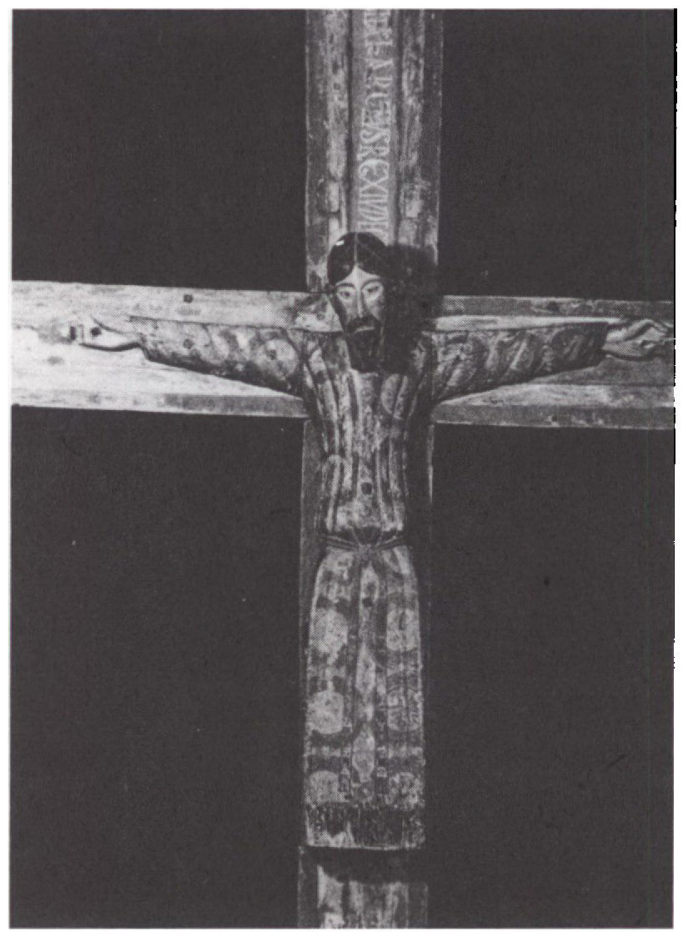

dybt modellerede linier $\mathrm{i}$ hånden, kan have ført til den opfattelse, at skikkelsen var bundet til korset. Mange afbildninger af Hjælperen viser denne bundet til korsarmene. Fødderne hænger frit og parallelle. Det oprindelige egekors er fornyet i nød og måler 4,34 x 2,65 m. Bag korset findes en $9 \mathrm{~cm}$ bred bue, der ender i sølvliljer. Buen er smykket med englehoveder og rosetter $i$ farvet glas.

Den er et udsmykningselement, der er kopieret over på mange Skt. Hjælperbilleder. Betydningen er ukendt; men jeg tolker den som en mandorla, svarende til den øverste halvdel af 8-tals mandorlaen, således som den kendes fra bl.a. Beatusapokalypsen (fig. 9). Hermed er vi igen tilbage både $\mathrm{i}$ tid (776) og sted (Gerona) ved de gamle majestaskors, hvis aner igen må søges i det gamle orient. ${ }^{21}$ Muligvis er det den samme mandorla, vi ser $\mathrm{i}$ Lisbjergalterets overbygning og i de gamle irske ringkors.

I det 12. århundrede blev San Frediano basilikaen renoveret og krucifikset overført til den nyopførte domkirke San Martino. Her er det anbragt $\mathrm{i}$ et 8-kantet kapel (fig. 10), hvorfra det hver år under en 


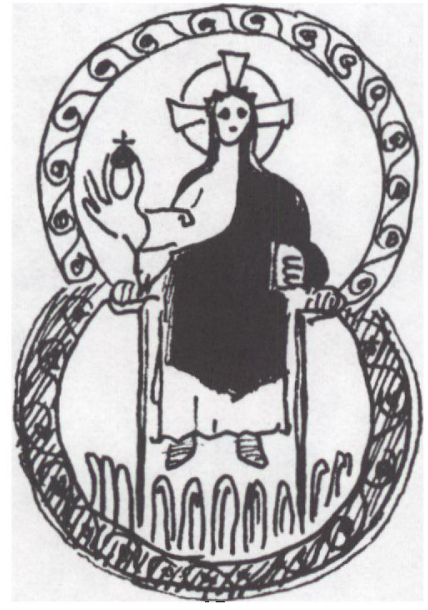

Fig. 9. Majestas fra Beatusapokalypsen (dr 776).

lysfest den 14. og 15. september i procession bliver båret gennem Luccas gader. Efter overførslen til domkirken har ingen turdet ændre på Volto Santo, ${ }^{13}$ men forinden har den gennemgået en sælsom forvandling. På skikkelsens hoved er anbragt en sølvkrone, hvori der er indfældet et portræt af Gud. Om halsen hænger en krave med engle og liljer. Fra begge håndled hænger brede, broderede strimler. Brystet er dækket af et gammelt brudesmykke, således som det kendes fra Bayern i ældre tid. ${ }^{10}$ Fra midjen og ned er figuren iklædt en rigtig kvindenederdel af fløjl, broderet med blomster. Nederdelen ender i en frynsekant, der delvis dækker fødderne, der er blevet iklædt sølvsko (fig. 11).

Under højre sko står en kalk, der er åben i bunden, og hvorfra der leder et rør ned til en kiste til modtagelse af offergaver. Kalken er det eneste udstyr, der genkendes. Den går igen i mange krucifikser og kan herhjemme ses både ved Tirstrup- og Ørting korsene. Dens symbolske funktion er at opsamle den korsfæstedes hellige blod."

I dette kostume har datiden opfattet skikkelsen som en kvinde, idet nederdelen blev anvendt til at lægge over kvinder i barselsnød. ${ }^{9} \mathrm{Hvad}$ der har fremkaldt kønsskiftet i San Frediano basilikaen, ved vi intet om. Kirken er opkaldt efter en irsk munk Frigidian, der kom fra Ulster. Han blev Luccas første biskop og døde i 588. I den smule, vi ved om hans liv, ligger der ingen forklaring.

Allerede fra midten af det 12. århundrede var »det hellige kors-Volto Santo« så kendt ude i Europa, at engelske konger aflagde ed "per Sanctum Vultum de Lucca«, og franske konger svor ved "Saint Vaude- 
Fig. 10. Volto Santo-kapellet $i$ San Martino domkirken i Lucca.

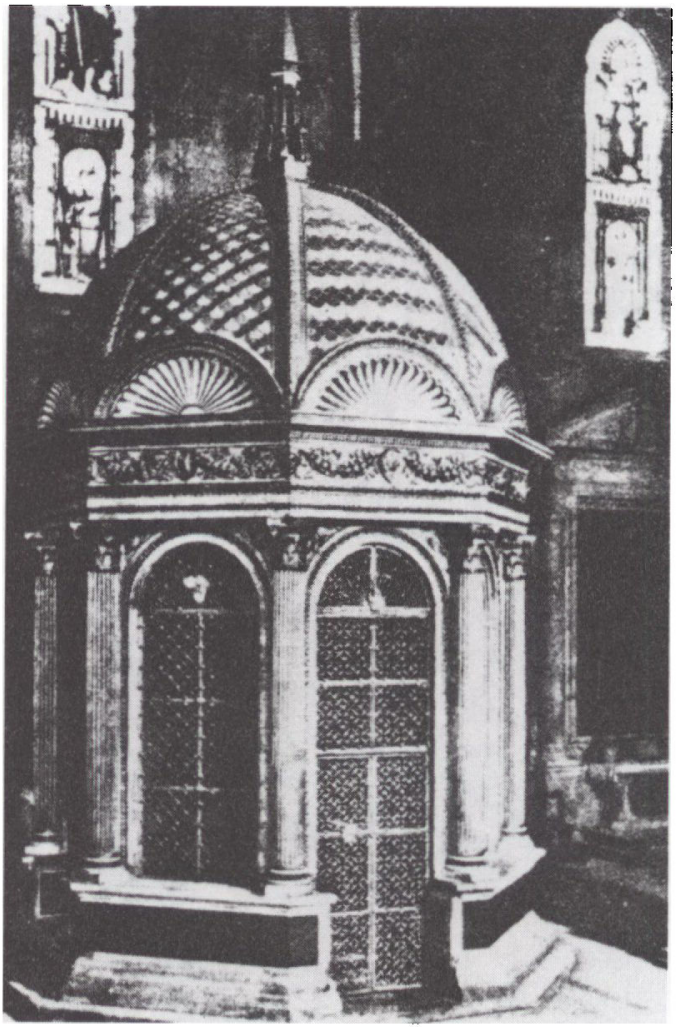

luc« (Sankt Volto de Lucca). Også kong Erik Ejegod har knælet ved det. ${ }^{12}$ Efter Raimbert de Paris' digt fra samme periode kom Karl den Store til Lucca og of rede der en frakke med glinsende guld og 30 mark fint guld og sølv til Volto Santo for, at Gud skulle sende Holger Danske, som han forfulgte, stor skam.

Gennem tiderne har 11 paver kysset dette mærkelige krucifiks. Midt i 1300-tallet var denne mands/kvindeskikkelse så kendt, at mange af de elskede sagn og beretninger, som var i omløb, blev tilpasset dette billede og af troubadourerne bragt omkring blandt adelen. Kümmerniss-Hjælperkulten har sit udspring i Tyrol og Lombardiet og har herfra bredt sig over det meste af Europa.

Legenden findes $i$ et utal af varianter, der alle kan føres tilbage til 3 grundformer - egentlig 2 varianter af samme fortælling, samt en helt afvigende form. 


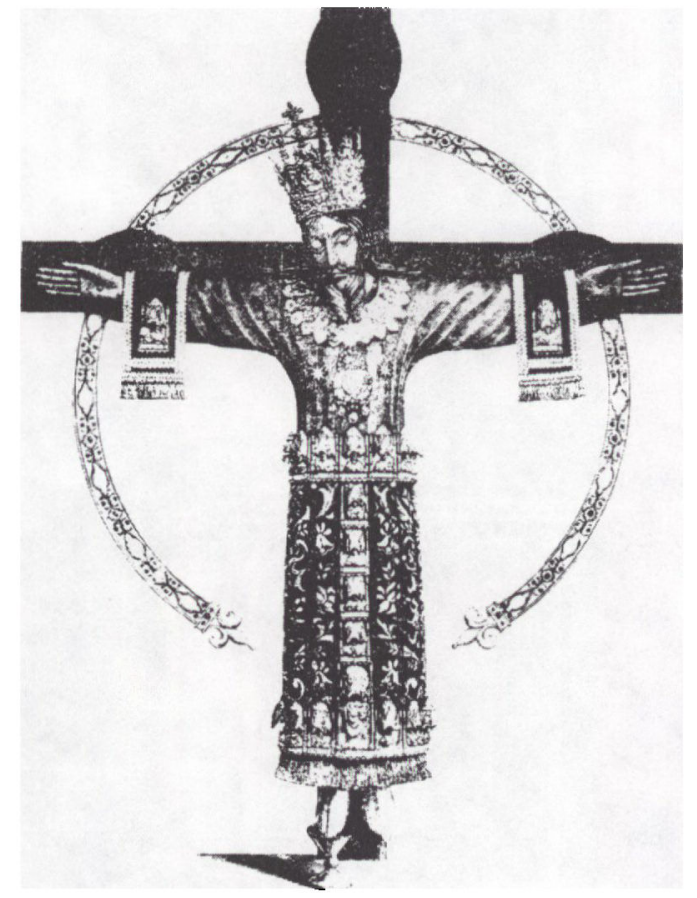

Fig. 11. Volto Santo-figuren fra San Martino domkirken i Lucca. Figuren er ikladt nederdel, krone og smykker. Over handleddene ses broderede stykker, og fodderne er ifort solvsko. Bag figuren en bred bue, der ender i solvliljer.

Legenden lyder: »Der boede en konge i Portugal, der ville bortgifte sin underskønne datter til en siciliansk prins. Prinsessen var kristen og havde lovet sit liv til Kristus, der til gengæld ville give hende en plads i paradiset. Prinsessen nægter derfor at tage den hedenske sicilianske prins til agtemage, og faderen straffer hende ved at lade hende indespærre $\mathrm{i}$ borgens fangekælder.

Variant 1: Om natten får hun besøg af Kristus, der trøster og døber hende. Hun beder så mindelig om at blive forskånet for den skæbne, hendes far har tiltænkt hende. Hun sover ind, og da hun vågner, har hun skæg som en bonde (quasi fuisset vir rusticalis).

Variant 2: Om natten får hun besøg af jomfru Maria med det lille Jesusbarn på armen. Jomfru Maria er ledsaget af 6 helgener. De hører på hendes klager og overrækker hende en forlovelsesring. Blødgjort af hendes bønner forvandler de hende til en mand, der er en tro kopi af Kristus. ${ }^{10}$

Da faderen opdager, hvad der er sket, bliver han så fortørnet, at han lader datteren korsfæste for hendes opsætsighed. En fattig spillemand kommer forbi og bliver grebet af medlidenhed. For at lindre den 


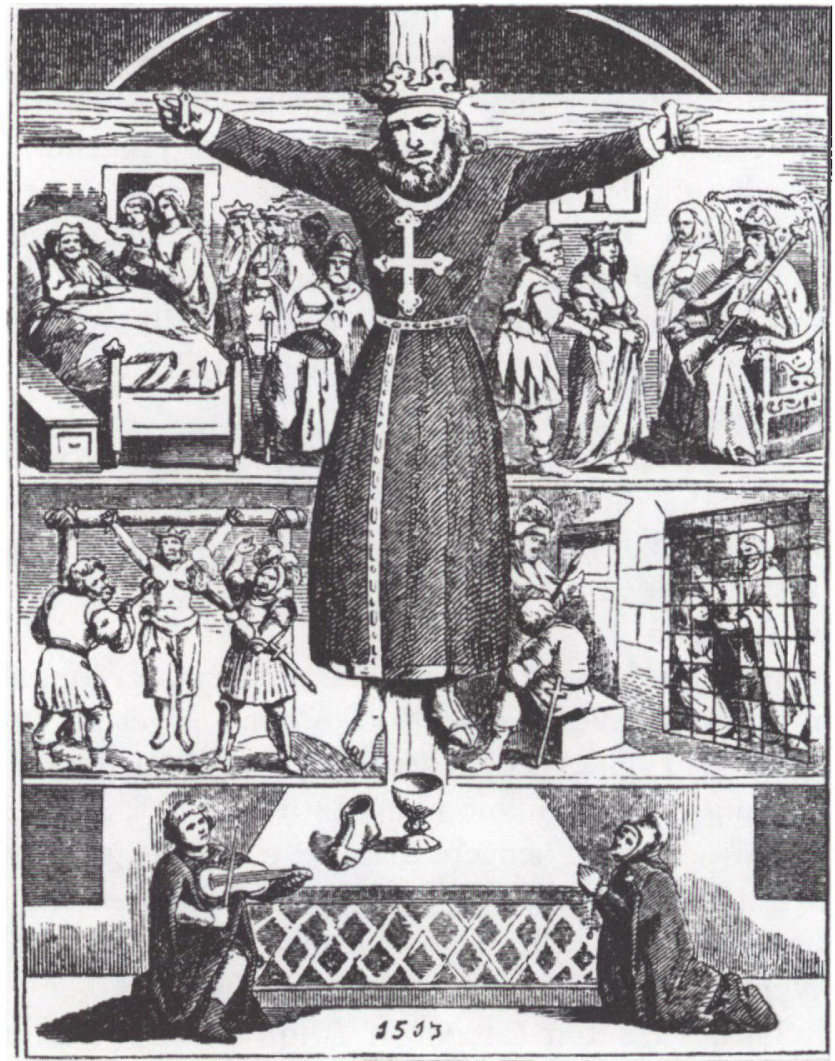

Fig. 12. Eltersdorftavlen. Kümmernissillustration fra 1503.

korsfæstedes pinsler, spiller han en melodi, og hun tilkaster ham til tak en af sine gyldne sko. Man tror, at spillemanden har røvet skoen og vil henrette ham derfor. På henrettelsespladsen anråber han Gud, og bøddelens arme bliver helt stive og får først deres bevægelighed, da dommeren ændrer dommen. Da lyder fra himlen Kristi stemme: "Store undere skal ske for de, der beder til dette kors«. Kristus tager derpå prinsessen op i himlen $\mathrm{i}$ hendes oprindelige skikkelse. Hele befolkningen takker Gud for det undergørende budskab, og hos alle var det slut på nød og elendighed.«

På en tavle fra Eltersdorf, der er malet i 1503, er hele variant 2 gengivet. Tavlen er vist som fig. 12.

Den tredie version af legenden, således som den særligt kendes fra det sydlige Tyrol, lyder: "En portugisisk konge lovede sin døende 
dronning, at han kun ville ægte en pige, der var lige så smuk som dronningen, og som kunne passe dronningens sko. Kun én pige opfyldte kriterierne, og det var deres fælles datter. Hun vil ikke giftes med faderen, der lader hende kaste i tårnets fangehul. Prinsessen har en tilbeder, og det er spillemanden, der er begavet med en guddommelig kraft. Han skaffer sig adgang til fangehullet og hjælper prinsessen til flugt $i$ en pels "af mange dyr«. Hun bliver fanget og bundet til et træ. Spillemanden dukker op, og prinsessen tilkaster ham en gylden sko. Spillemanden spiller så alle båndene brister og tager derpå prinsessen til agter.

Sidste version synes at danne ophav til de to første, og man aner duften af ældgamle frugtbarhedsriter. Alle ingredienserne er til stede de mange dyr, frugtbargørelse af træer og andre vækster, båndene, der brister, og den tilkastede sko, der jo er en kun slet skjult opfordring til elskov.

Man har da også søgt legendens kilder over longobarderne ind i den nordiske mytologi. Tyske forskere har peget på Tor, der også kunne optræde i kvindeklæder eller sagnet om Odin, der forklædt som kvinde, besvangrer den bundne kongedatter Rind. Legendens kilder skal dog nok søges endnu længere tilbage $i$ orientens gudeverden.

Det har dog ikke bekymret middelalderens adel, der har nikket genkendende til alle legendens enkeltelementer. Det var kært stof, der hyppigt indgik $\mathrm{i}$ deres fortællinger og sange.

Således beretter Gregor af Tours (540-94) om bryllupsfester, hvor bruden bliver meget deprimeret og græder, efter at parret er lagt på samme leje. Hun betror sin ægtemand, at hun har lovet Jesus sit jomfrulegeme urørt og uplettet af nogen mand. Manden forstår hende, og de deler lejet og ægteskabet i kyskhed.

Tvekønnethed optog middelalderen meget, og tempelridderne aflagde ed til Baphomet eller Baffemet, der var en nøgen jomfru med fuldskæg. Til yderligere understregning af biseksualiteten havde hun en slange om livet. ${ }^{15}$

Hos Diakonus (725-95) berettes om longobarderne, der var ved at halshugge en hellig mand. Da denne anråbte Gud, skete det for bøddelen, at "straks blev hans højre hånd stiv under selve stødet, og han kunne ikke trække den tilbage til sig og måtte slippe sværdet, der faldt til jorden «. ${ }^{16}$

Fra sagnkredsen om Theodorik den Store (»Didrek «) (454-526) findes fortællingen om kong Rother, der indeholdt mange af legendens elementer. Rother kommer forklædt som Didrek til kong Konstantins 
Fig. 13. Tysk ex voto-tavle fra 1886 med Sct. Hjalper, en gave, skanket til en kirke i taknemlighed for helgenens hjalp (ex voto = ifolge lofte).

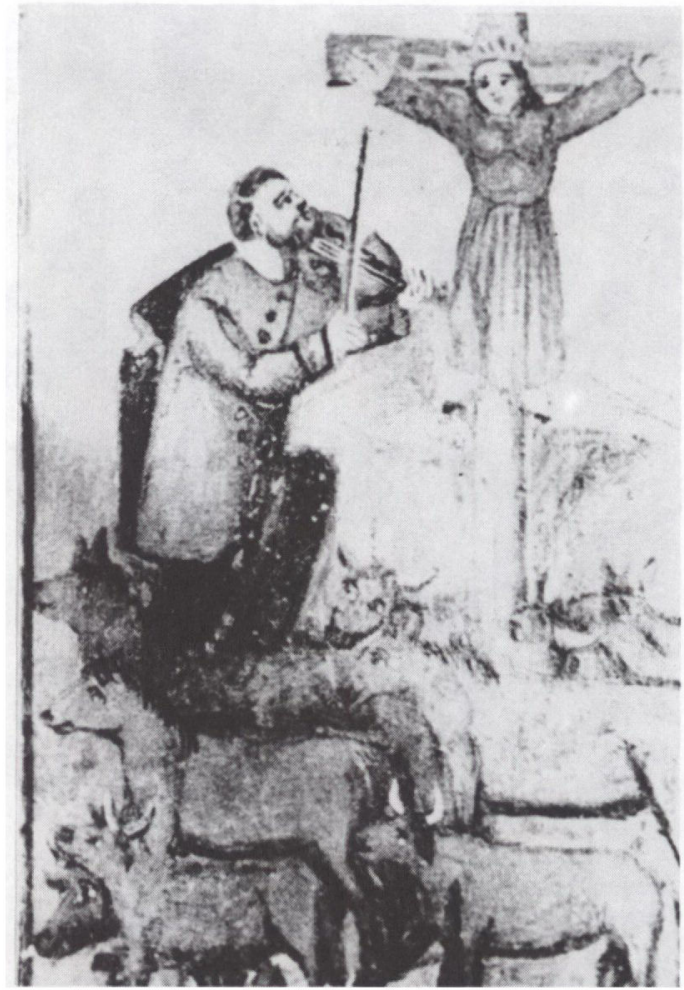

hof og spiller både på harpe og horn med uventede resultater. Han modtager såvel en sølv- som en guldsko af prinsessen. Begge er venstresko, og Didrek skal finde deres mager. Ved list løses opgaven, og han får adgang til den underskønne prinsesse. Han fanges og skal hænges, men befris af sine mænd, der hører hans hornsignal. Også fangehullet optræder, omend som opholdssted for Didreks gesandter. Efter flere kvaler får Rother sin prinsesse og deres barn, Pipin, bliver fader til Karl den Store, som ofrede sin kappe til "Volto Santo« i Lucca.

Også en beretning om kong Oswald af Northcumberland (605-42), der var særlig levende i Tyrol og Norditalien, indeholder elementer, der genfindes i legenden om Hjælperen.

I det 15. århundrede blev der oprettet selskaber i Hjælperens navn, og der blev opført passionsspil til dennes ære. I Danmark kendes fra Svendborg et Sct. Hjælpers Gilde og fra Flensborg og København "sancti Hjelpers Altare«. Over hele Nordtyskland var sangen om "Spil- 

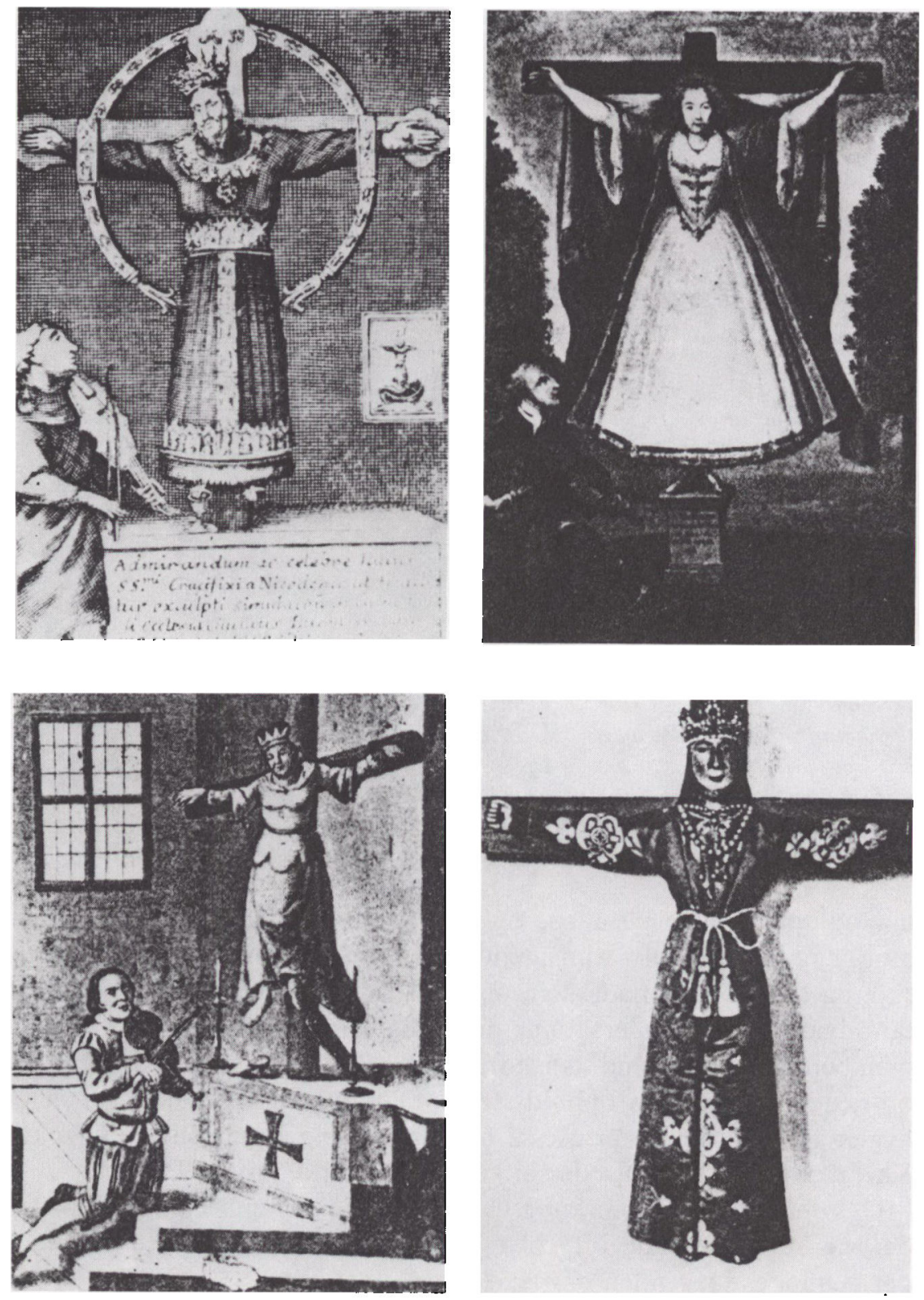

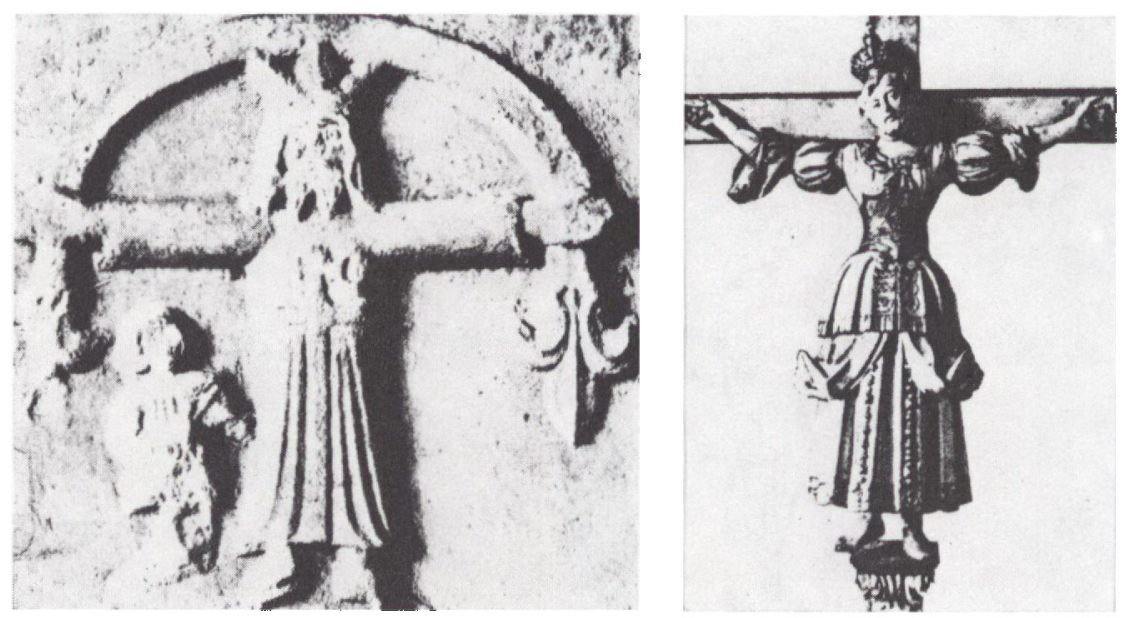

Fig. 14. Et udvalg af Sct. Hjalper (Kümmerniss) billeder, der viser bredden i fremstillingen. Afbildingerne stammer fra Graz, Breslau, Neisse, Brügge, Oberwintherthur og Hüfingen.

lemanden fra G'münd « kendt, og i kirkerne blev sunget salmen: »O heilige Kümmerniss vor Dir fall' ich auf meine Füss«. Så sent som i 1696 skrev Augustiner barfodsmunken Bernadus et epos om "En velduftende Rose fra Portugal.$^{10}$

Trods legendens uomtvistelige popularitet har kirken aldrig villet kanonisere Sct. Hjælper og er veget udenom at tage stilling til denne helgen. I Martyrologium Romanum er dog indført under den 20. juli: "I Portugal har den hellige jomfru og martyr Wilgefortis - for sin rene kristne tro og smukke kyskhed på korset fortjent vundet sin triumf «.

Første beretning om kulten stammer fra midten af 1300-tallet. Den når sit højdepunkt 200 år senere for så at klinge ud midt $\mathrm{i}$ det 18 . århundrede. Enkelte steder har den dog levet videre, jfr. Ex-Voto tavlen fra 1886 (fig. 13). Det sidste vidnesbyrd om kulten har vi fra sognekirken i Lienz, hvor der hænger en tavle med indskriptionen: "St. Kümmerniss hat geholfen 1931 «.

Da reformationens billedstormere ryddede ud i kirkerne, overlevede mange Kümmerniss billeder, der blev opfattet som billeder af jomfru Maria. Uden større postyr blev helgenens kapeller til andagtsteder for jomfru Maria.

Når derfor kirkehistorikeren Carsten Petersen beretter om de mange Mariabilleder, der fandtes i Kliplev kirke frem til 1775, er det nærliggende at tro, at der blandt dem har været flere Sct. Hjælper billeder. ${ }^{17}$ 


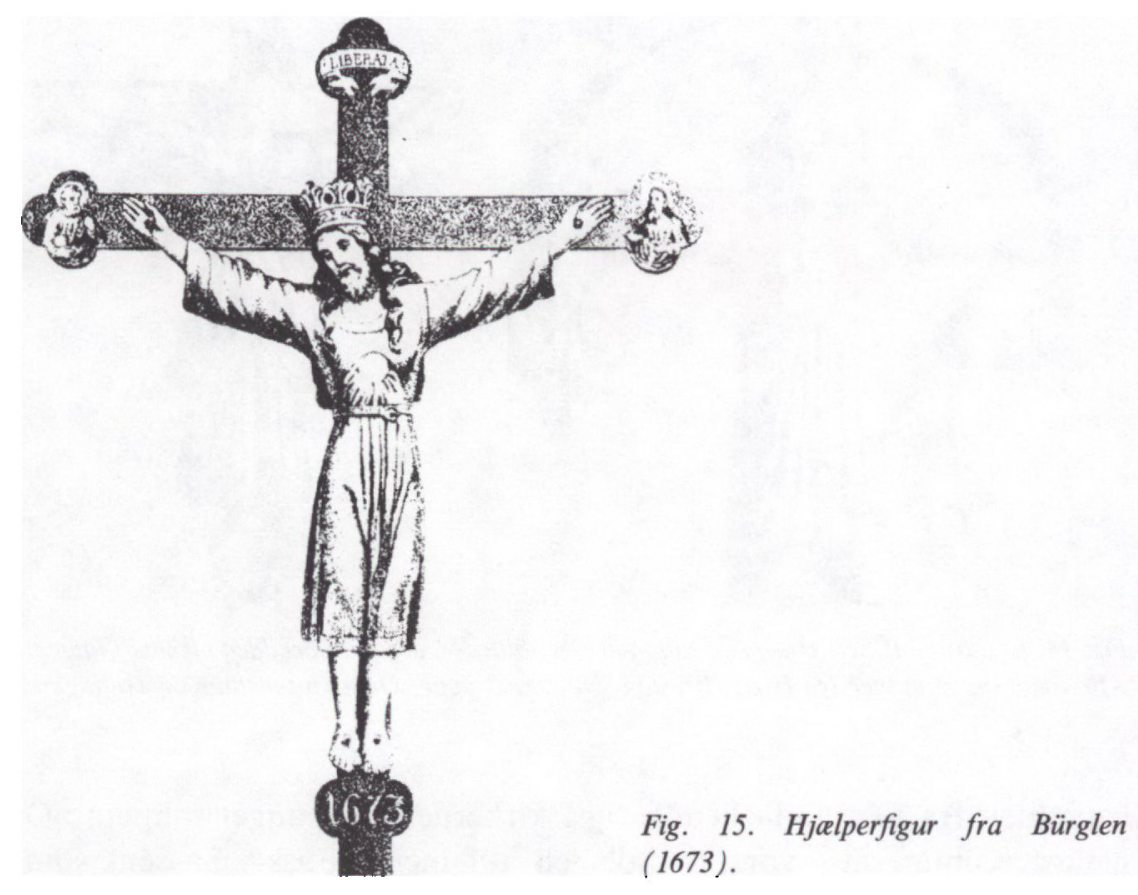

Dette kan igen bestyrke formodningen om, at nordkapellets helgen har haft en jomfrus skikkelse. Med udgangspunkt $i$ legendens varianter kan helgenen udformes som en korsfæstet prinsesse med eller uden skæg, men også som en kjortelklædt mandsfigur, Kristus lig.

Der findes mange varianter, der nu er havnet på tyske museer. Et udvalg er vist som fig. 14. Fra Danmark er, når der ses bort fra Nustrup-krucifikset, kun kendt nogle grove pilgrimsmærker, hvoraf Kværsmærket er det absolut bedste.

Hvor vi træffer den mandlige, kofteklædte skikkelse med hænderne naglet til eller bundet til korset og med parallelle, ubundne fødder, står vi med stor sikkerhed over for en hjælperafbildning. Til illustration heraf er valgt fig. 15. Direkte på den lodrette korsarm står "Liberata«. Det er et af hjælperens mindre kendte navne, og det siger entydigt, at der ikke er tale om en Kristusfigur. Krucifikset er fra $1673 \mathrm{og}$ føddernes naglegab er en senere tids forbedring. Sct. Hjælper er i denne udformning blevet skånet ved reformationen, idet skikkelsen er blevet opfattet som et Kristuskrucifiks. 


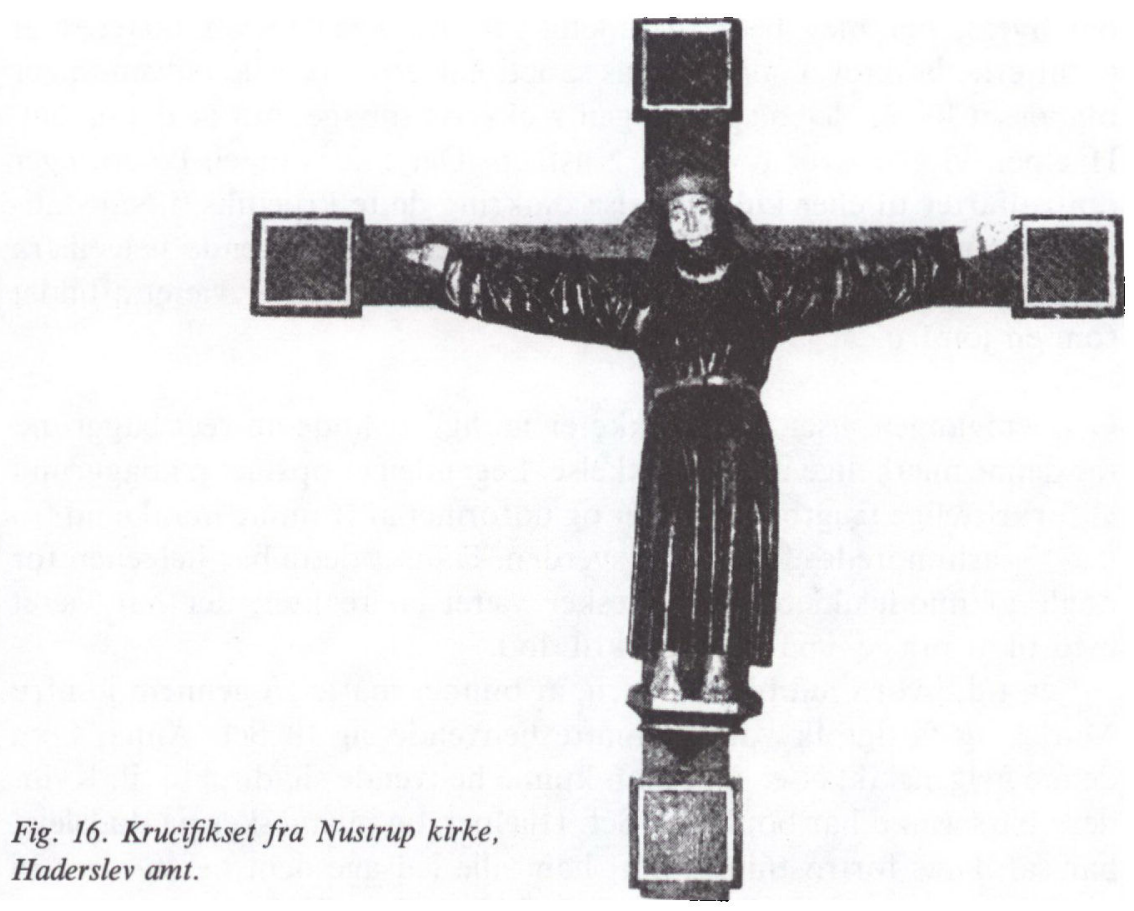

Således kan vi da også den dag i dag møde Skt. Hjælper i Nustrup kirke. Det drejer sig om et sengotisk krucifiks, hvor den korsfæstede er en kjortelklædt mand med fuldskæg. På hovedet bærer han en krone, og de parallelle fødder hviler på en konsol. Naglerne er faldet ud, men både hænder og fødder viser udboringer til naglerne. For føddernes vedkommende kan borehullerne muligvis være udført efter reformationen.

Nustrup krucifikset er vist som fig. 16. Som det fremgår af billedet, er der tale om et evangelistkors, dog uden spor af evangelisterne eller deres symboler $i$ de hertil beregnede felter. Der findes ingen forbindelse fra Skt. Hjælper til evangelisterne, hvorfor evangelistkorset har ført til usikkerhed m.h.t. figurens identitet. Jeg vil dog tro, at korsarmenes kvadrater er et rent dekorativt element, jf. fig. 15.

Når Nustrup-krucifikset i tidligere indberetninger er blevet opfattet, som Frelseren på korset (»Salvator mundi«) kan dette ikke bruges som argument til afgørelse af identiteten. Hjælperkultens højborg i middelalderen var Hülfensberg ved Heiligenstadt. Her var enhver tvivl 
om hvem, der blev bedt til, udelukket. Alligevel blev kultstedet af jesuitterne beskrevet som »Mons sancti Salvatoris«. Alle indvendinger tilgodeset bliver der næppe nogen reel tvivl tilbage, om at det er Sct. Hjælper, vi står over for her i Nustrup. Der findes ingen beretninger om valfarter til eller kultdannelse omkring dette krucifiks. ${ }^{18} \mathrm{Når}$ datidens almue ikke i figuren har genkendt den undergørende helgen fra Kliplev, bestyrker også det opfattelsen af, at sidste har været afbildet som en jomfru.

Gennemgangen viser, at det ikke er muligt at finde en reel baggrund for denne mærkelige helgenskikkelse. Legenden er opstået på baggrund af førkristelige frugtbarhedsriter og udformet af fromme munke ud fra det 13. århundredes forestillingsverden. Uanset dette har helgenen for nogle af middelalderens mennesker været en realitet, der har været med til at præge dem fra fødsel til død.

I en tid, hvor Gud blev så fjern, at bønner måtte gå gennem jomfru Maria, og fattigfolk ydmygt måtte henvende sig til Sct. Anna, kom denne helgenskikkelse, som man kunne henvende sig direkte til. Kvinder $\mathrm{i}$ barselsnød har bønfaldet Sct. Hjælper, og mennesker på dødslejet har sat deres fortrøstning til, at han ville ledsage dem og stå dem bi på den anden side. I alle livets forhold har Sct. Hjælper ydet bistand - fra hjælp til afgrøder og studehandler - til støtte i sygdom og fortvivlelse.

Helgenen er en del af vor kulturarv, og uanset dens mærkelige baggrund må den have krav på vor interesse, særligt i denne landsdel, hvor den synes at have haft så stor betydning.

\section{LITTERATURHENVISNINGER}

Numrene refererer til henvisningsnumrene i teksten.

1. Ellen Jørgensen: Helgendyrkelsen i Danmark. 1909.

2. H. V. Gregersen: Messe og Marked. Haderslev 1974.

3. L. Bobé: Ahlefeldternes Historie. 1898-1912.

4. N-K. Liebgott: Afstøbninger af pilgrimstegn på danske middelalderlige kirkeklokker (Arboger for nordisk oldk. og hist. 1971).

5. Heimreich: Schleswigsche Kirchen Historie. 1683. (Schleswig).

6. Die Kunst- und Geschichts-Denkmäler des Grossherzogthums Mecklenburg-Schwerin (Schwerin 1896 - bd. 1).

7. Kr. Kaalund: En islandsk vejviser for pilgrimme fra det 12. århundrede (Årbeger for nord. oldk. og hist. 1913). 
8. G. Schnürer og J. Ritz: St. Kümmerniss - Volto Santo. (Forschung zur Volkskunde Heft 13-15, Düsseldorf 1934.)

9. K. Rehorn: Der heilige Kumernus oder die heil. Wilgefortis. Ein Beitrag zur Geschichte und Deutung eines alten Cultus. (Germania 1887).

10. K. v. Spies: Marksteine der Volkskunst II. Berlin 1942.

11. P. Nørlund: Gyldne altre. 1926.

12. Danmarks kirker v. E. Molkte, E. Møller og V. Michelsen. 1933. (Åbenrå og Haderslev Amter).

13. Mr. L. A. I. W. Baron Sloet: De heilige Outkommer of Wilgefortis. Een geschiedkundig onderzoek. Gravenhagen 1884.

14. O. Wimmer: Lexikon der Namen und Heiligen. Wien 1982.

15. P. Lauring: Danmarks Håb og Horn. 1954.

16. Paulus Diaconus: Longobardernes Historie. 1897 (dansk oversættelse).

17. C. Petersen: Kirker i Åbenrå Provsti (Sønderjyske Årbøger 1941).

18. S. Steffensen: Nustrup Sogn. Nustrup 1971.

19. M. Mackeprang: Afvigende Krucifixformer (Årbeger for nord. oldk. og hist. 1907).

20. J. F. C. Uldall: Danmarks middelalderlige Kirkeklokker. 1906.

21. H. B. Meyer: Zur Symbolik frühmittelalterliche Majestasbilder. (Das Münster 1961).

Ordforklaringer

Korsdagene I den katolske kirke fejres korsmesse til erindring om fundet af Kristi "sande« kors 3/5 616 og korsets genanbringelse på Golgatha 14/9 629. Dagene benævnes: Genfindelsesdagen og Ophøjelsesdagen.

Passionale Passionale er en legendesamling ordnet efter kalenderen.

Mandorla Mandorla kaldes den aflange mere eller mindre mandelformede strålekrans, der på middelalderbilleder omgiver Kristus, Maria eller betydningsfulde helgener.

Martyrologium Martyrologium er et officielt register over kristne martyrer.

M.Romanum er en i 1584 fremstillet oversigt baseret på M.Usuardus fra 875. På fremstillingstidspunktet for $\mathrm{M}: \mathrm{R}$. har Hjælperkulten været så betydningsfuld, at den ikke kunne forbigås. 
